Article

\title{
A Pro-Environmental Reasoned Action Model for Measuring Citizens' Intentions regarding Ecolabel Product Usage
}

\author{
Reny Nadlifatin ${ }^{1,2, *}$, Shu-Chiang Lin ${ }^{1}$, Yulia Puspa Rachmaniati ${ }^{1}$, Satria Fadil Persada ${ }^{3}$ \\ and Mohammad Razif ${ }^{4}$ \\ 1 Department of Industrial Management, National Taiwan University of Science and Technology, 43, \\ Keelung Rd, Da'an Dist, Taipei 106, Taiwan; slin@mail.ntust.edu.tw (S.-C.L.); \\ m10401835@mail.ntust.edu.tw (Y.P.R.) \\ 2 Department of Informatics Engineering, University of 17 Agustus 1945 Surabaya, 45th Semolowaru, \\ Surabaya 60118, Indonesia \\ 3 Department of Business Management, Institut Teknologi Sepuluh Nopember (ITS), Surabaya 60111, \\ Indonesia; satriafadil@mb.its.ac.id \\ 4 Department of Environmental Engineering, Institut Teknologi Sepuluh Nopember (ITS), Surabaya 60111, \\ Indonesia; razif@its.ac.id \\ * Correspondence: d10201806@mail.ntust.edu.tw or reny.nadlifatin@gmail.com; Tel.: +886-2-2737-6330
}

Academic Editor: Marc A. Rosen

Received: 8 August 2016; Accepted: 4 November 2016; Published: 11 November 2016

\begin{abstract}
Ecolabel products are one approach towards environmental sustainability. Ecolabel programs have been socialized by governments all over the world to reduce environmental harm caused by the daily life cycles of the products that citizens use. The present study was aimed at measuring citizens' behavior intention (BI) regarding ecolabel product usage. An extended theory of reasoned action (TRA), namely that of pro-environmental reasoned action (PERA), is used as the predictor model. A total of 213 questionnaire data, collected from citizens of Indonesia, was analyzed using structural equation modeling. The analysis results show that the PERA model is able to describe $68 \%$ of citizens' BI regarding ecolabel product usage. The analysis results also reveal that attitude is a key determinant factor. Several practical suggestions based on the results can be used as input for policy makers and company management to consider in their efforts to increase citizens' BI to use ecolabel products.
\end{abstract}

Keywords: ecolabel products; citizens; intention; pro-environmental reasoned action

\section{Introduction}

As populations all over the world continuously increase, production is evolving and increasing to fulfill the product demands. A product life cycle whose development process does not consider environmental perspectives surely leaves a serious negative impact that potentially harms the environment [1,2]. To preserve and to ensure environmental sustainability, many governments and environmental protection organizations all over the world promote the usage of green environmentally friendly products or "eco-products". Eco-products can be differentiated from regular products by their attached ecolabel. The ecolabel itself is designed to justify the use of green processes in a product's life cycle.

The world's first ecolabel program was introduced by the German Federal Minister of the Interior and the Ministers for Environmental Protection in 1977 with the name "Blue Angel". The Blue Angel program encouraged citizens to use environmentally friendly products, to urge manufacturing companies to produce less environmentally harmful products, and to use ecolabels as a market-oriented 
instrument of environmental policy. The concept of guiding societies and manufacturing companies towards caring about the environment was later followed by many other nations all over the world. Several examples of ecolabel implementation have been seen, such as Canada's Environmental Choice, the European Union Ecolabel Award Scheme in most EU nations, Ecomark in India, Green Mark in Taiwan, Green Label in Singapore, and Ekolabel in Indonesia [3]. In more detail, each of these nations have a guideline for ecolabel procedures from government or an appointed agency for manufacturers that want to certify their products. However, not only does the ecolabel program need support from government-related agencies and manufacturers, but the participation of citizens is also important to ensure the successful influence of ecolabel programs on a society's environment.

While many research studies show the influence of ecolabel procedures and policies on government and manufacturing companies [4-6], few have discussed citizens' points of view, especially with respect to behavior intention (BI). This study, therefore, investigates ecolabel product usage from the standpoint of citizens' intention. This study is also the first to address a well-known behavior model, a theory of reasoned action (TRA), with two additional factors as the measurement model for ecolabel product usage. Namely, perceived authority support and perceived environmental concern are combined as the antecedent factors in the TRA model and referred to as the pro-environmental reasoned action model (PERA). Here, ecolabel product usage in Indonesia is used as a case study. Indonesia is selected not only because it is the fourth largest country in the world in terms of population and because it is a developing country, but also because the inclusion regulation of the ecolabel logo in Indonesia was published as recently as 2014 [7]. The recent new inclusion logo policy surely provides much room for improvement, including from the standpoint of citizens. The new inclusion also serves as the best example of the PERA model to reveal the latent factors that influence the use of ecolabel products. The results of this study are expected to contribute an assessment of ecolabel usage from citizens' perspectives and to provide improvements and recommendations to entice citizens to use ecolabel products. If citizens want to use ecolabel products, the target market will increase and will incentivize manufacturers to produce many more environmentally friendly products. The global environment will eventually take less damage.

The structure of this article is arranged as follows. Section 2 explains the theoretical model of the PERA and the ecolabel program in Indonesia. Several hypotheses are made in this section. Section 3 describes the research methodology. Section 4 reveals the data analysis, results, and discussion. Section 5 concludes the study with limitations and recommendations for further research.

\section{Theoretical Framework}

The theory of reasoned action (TRA) is a behavior model introduced by Ajzen and Fishbein in an effort to describe the likelihood that a person's behavior will lead to a specific outcome [8,9]. In more detail, the intention outcome is predicted by two salient factors, namely attitude (AT) and subjective norm (SN). Intention is a representation factor that is able to capture human efforts to perform a particular behavior [10]. The intention itself leads to a specific action [11]. AT is the level to which an individual has a favorable evaluation in performing a particular behavior. $\mathrm{SN}$ is the perceived social pressure to perform a particular behavior. Some related model studies mention SN as the individual perception that is influenced by social environment, which has a significant influence on the individual's performing a particular behavior [12-14]. The concept of the TRA model inspired many well-known models such as the theory of planned behavior model [11], the technology acceptance model [15,16], and the unified theory of acceptance and use of technology [17]. The modified models use the TRA factors along with several new additional factors designed to examine a specific target behavior. The TRA model has been widely used for decades in the pro-environmental research area [18-21]. The present research develops an extended TRA model, namely the pro-environmental reasoned action (PERA) model, which adopts the concept of TRA and combines the TRA model with two additional factors. The additional factors consist of perceived authority support (PAS) and perceived environmental concern (PEC), and the model is shown in Figure 1. The PAS and PEC factors 
were previously tested by Persada [22] in the pro-environmental research regarding environmental impact assessment (EIA). The PAS and PEC show the positive influence on both AT and SN to describe citizens' EIA participation. Thus, the present study uses these particular factors together with a TRA model on ecolabel assessment.

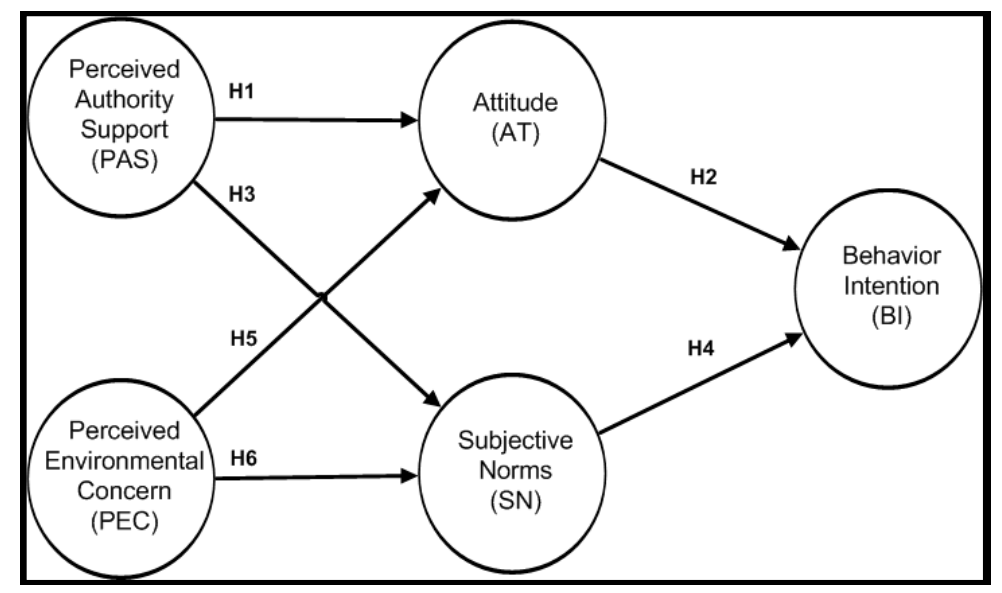

Figure 1. The pro-environmental reasoned action (PERA) model.

The role of government as an authority and a policy controller can substantively influence any business operation, including the existence of ecolabel products. Several studies mention that the government, as an authority support, can affect the implementation of pro-environmental activity by creating regulations and physical procedures that support the realization of pro-environmental activity $[5,13,23]$. Accordingly, the perceived authority support (PAS) can be seen as the individual perception of any resource, regulation, facility, and support provided by an authority agency or by government that can help individuals perform a specific behavior [14,22]. The Government of Indonesia, through the Ministry of Environment, initiated the Ekolabel program in 2006 [6]. However, the standardized inclusion logo was not declared until 2014 [7]. The Ekolabel program adopts the ISO 14024 and ISO 14020 concepts and provides two logos as can be seen in Figures 2 and 3.

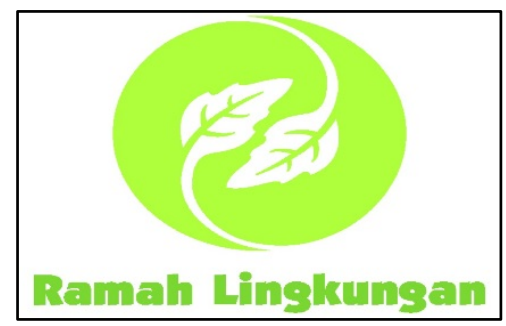

Figure 2. Ekolabel logo Type 1.

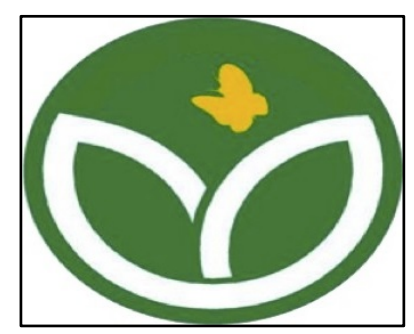

Figure 3. Ekolabel logo Type 2. 
The first ecolabel logo, Ekolabel Type 1, is provided to manufacturing companies who want to certify a product on multi-criteria standards, as mentioned in ISO 14024. In more detail, the Type 1 logo certification considers overall life cycle, which can be detailed as the production, the materials, the consumption, and the end life of a product. The National Accreditation Committee (Komite Akreditasi Nasional; KAN) is appointed by the Ministry of Environment as the agency responsible for conducting the certification process. The second ecolabel logo, Ekolabel Type 2, is provided as a verification logo for the self-declared process (Swadeklarasi). The self-declared process means that a company can apply for one or many environmental parameters that undergo green processes in the product life cycle. The self-declared logo adopts ISO 14020, and only a few registered agencies appointed by the Ministry of Environment can certify the logo.

In order to obtain an ecolabel license, the manufacturer must fulfill certain prerequisite environmental aspects. These requirement aspects are aimed to protect the environment as well as to provide a guarantee of a good environmentally friendly product from manufacturers to citizens [6]. When all the necessary documents are prepared, the manufacturer can apply for certification by submitting documents to the relevant certification agency, as shown in Figure 4 [24]. The submitted documents are later inspected by the secretary as an administration check. An adequacy audit is performed to ensure the documents are sufficiently complete. Through the adequacy audit, the field and sampling preparations are conducted. In the field audit, the agency delegates their representation to inspect the location and to verify the compatibility between the descriptions in the documents and the field situation. In the sampling and testing audit, the team further checks the conformity between the explanation in the documents and the real product specifications (i.e., the team will take a sample of the product and test it in a laboratory). Both the field and sampling audit results are evaluated by the auditor who completes an evaluation report. The evaluation report is used by the committee as material for a meeting. In the meeting, members decide on the feasibility of issuing the certificate.

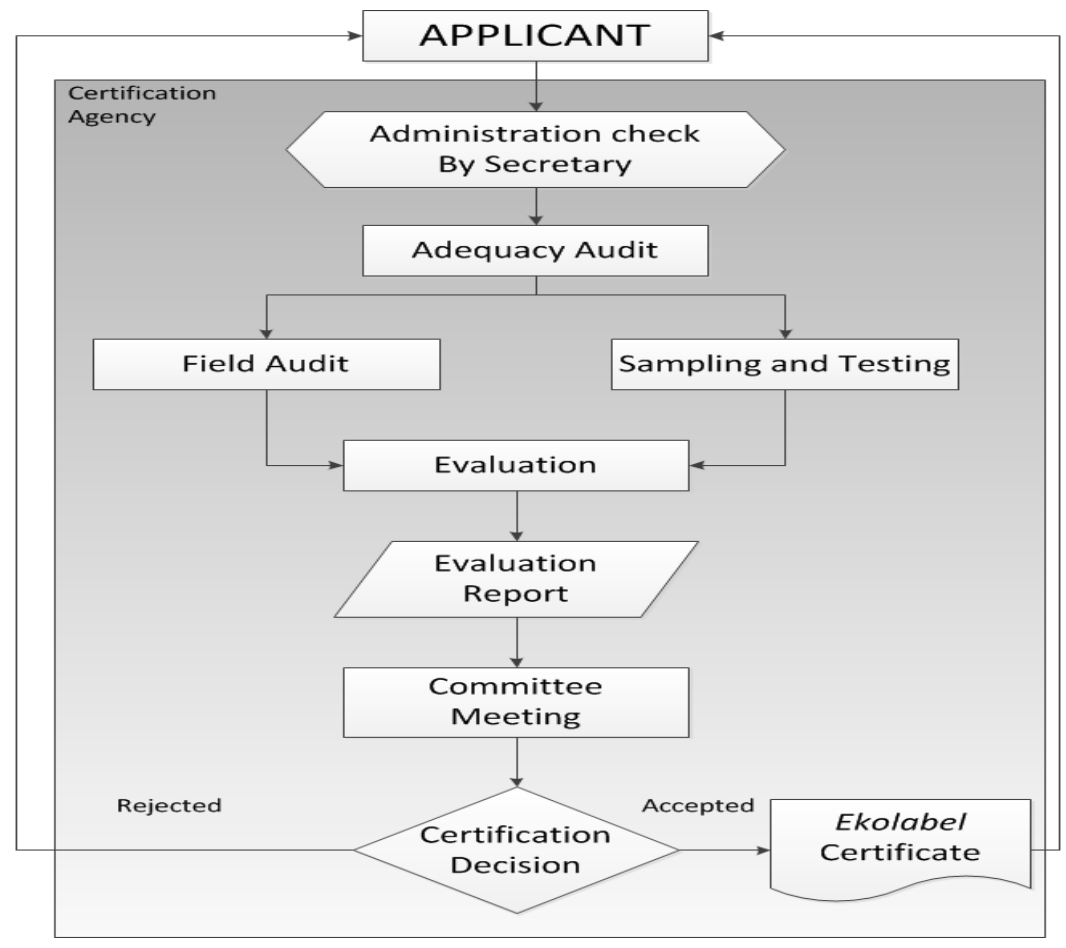

Figure 4. English-translated version of the certification process [24].

The Government of Indonesia not only provides environmental regulations to ensure environmental sustainability from a manufacturing perspective, but also tries to actively entice citizens to utilize the pro-environmental activity program, including the use of ecolabel products. The 
attraction is similar to other countries' approaches in terms of socialization, incentives, and rewards. Thus, the role of government as an authority support can positively influence citizens' personal attitudes as well as their social surroundings in an effort to improve perception. The current research examines individuals' attitudes as well as the social norms influenced by the PAS factor in how ecolabel product usage is perceived. Several pro-environmental studies have confirmed the positive role of authority support in encouraging individuals to conduct pro-environmental activity [13,14,22,23]. Hence, the following hypotheses are proposed to test the correlation of the AT and SN factors for ecolabel product usage behavior:

H1: PAS has a positive relationship with AT in citizens' ecolabel product usage behavior.

H2: AT has a positive relationship with BI in citizens' ecolabel product usage behavior.

H3: PAS has a positive relationship with SN in citizens' ecolabel product usage behavior.

H4: SN has a positive relationship with BI in citizens' ecolabel product usage behavior.

Perceived environmental concern (PEC) is the individual feeling regarding any physical activities leading to pro-environmental consequences [14]. Many studies have validated the existence of environmental concern in encouraging individuals to conduct pro-environmental activity $[13,14,22,25-28]$. The present research evaluates individual attitudes and social norms through the PEC factor in response to ecolabel product usage. The assumption of positive correlations between PEC with AT and PEC with SN are proposed based on the similarity factor analysis research in pro-environmental activity $[13,14]$. Thus, the following hypotheses are made:

H5: PEC has a positive relationship with AT in citizens' ecolabel product usage behavior.

H6: PEC has a positive relationship with SN in citizens' ecolabel product usage behavior.

\section{Methodology}

The present study focused on evaluating citizens' intention regarding ecolabel product usage. The extended TRA model, namely the pro-environmental reasoned action (PERA) model, was used, and a questionnaire as an instrument to collect the data was collected. The questionnaire consists of two sections in which the first section assesses the five factors with a 5-Likert scale. The 5-likert scale ranges from 1, "I strongly disagree," to 5, "I strongly agree," and each of the factors has 3 questions. The questionnaire partially adopts and modifies the questionnaire used by Persada [22] regarding citizens' EIA assessment. In more detail, Section 1 of the questionnaire is shown in Table 1. The second section retrieves background information such as age, gender, and place of origin. The questionnaire was gathered from January to June 2016. Both online and offline questionnaires were conducted by the convenience sampling method, and citizens of Indonesia with a minimum age of 17 years old were targeted. This age was chosen because, at 17 , citizens have the full rights to legal action in accordance with the constitution. The online questionnaire was conducted by providing an online form of questionnaire that can be accessed through the Internet. The offline questionnaire was conducted by distributing a paper-based question in several locations. A structural equation modeling (SEM) analysis was used as the analysis tool. SEM was conducted to assess the structural correlation between interconnected factors. SEM was used because of its ability to reveal causal relations in sample data in a path analysis; moreover, .multiple correlation problems can be analyzed $[5,29]$. This study also employed confirmatory factor analysis (CFA), which confirmed the positive correlation in the model through the hypothesis statement. Furthermore, many confirmatory factor analysis studies have been conducted by utilizing SEM to confirm the influence value on each correlation [30,31]. Six hypotheses, developed in five factors, are tested via SEM in this study. 
Table 1. Questionnaire design adapted from Persada [22].

\begin{tabular}{cl}
\hline Factors & \multicolumn{1}{c}{ Questions } \\
\hline PAS1 & $\begin{array}{l}\text { I feel have a chance to use the programs provided by the government or the related authorities } \\
\text { with the use of ecolabel products in an effort to reduce environmental problems. }\end{array}$ \\
\hline PAS2 & $\begin{array}{l}\text { The government or the related authorities give me the freedom to make my own decision[s] to } \\
\text { use [...] ecolabel products. }\end{array}$ \\
\hline PAS3 & $\begin{array}{l}\text { I feel that I have the option to participate in environmental activities established by the } \\
\text { government and related authorities by using [...] ecolabel products. }\end{array}$ \\
\hline PEC1 & $\begin{array}{l}\text { I am very worried about the state of the world environment and what that will mean for my } \\
\text { future, so I need to keep the environment by using the ecolabel products. }\end{array}$ \\
\hline PEC2 & $\begin{array}{l}\text { Humans are very often misusing [or] damaging the environment, so it is necessary for me to } \\
\text { help save the environment by using [...] ecolabel products. }\end{array}$ \\
\hline PEC3 & $\begin{array}{l}\text { When human[s] interfere with nature, nature produces disastrous consequences. I need to } \\
\text { overcome it by using [...] ecolabel products to avoid [or] reduce the disruption of nature. }\end{array}$ \\
\hline AT1 & I think the use of ecolabel products is very good. \\
\hline AT2 & [I want to] use [...] ecolabel products. \\
\hline AT3 & [I love to] use [...] ecolabel products. \\
\hline SN1 & Most of the people who are important to me think I have to use the ecolabel products. \\
\hline SN2 & Most of the people who are important to me want me to use the ecolabel products. \\
\hline SN3 & Most of the people who are pretty important to me [prefer that I] use the ecolabel products. \\
\hline BI1 & I am willing to use the ecolabel products. \\
\hline BI2 & I plan to use the ecolabel products. \\
\hline BI3 & I will try to use the ecolabel products. \\
\hline
\end{tabular}

\section{Results}

\subsection{Data Analysis}

A total of 213 respondents, from ages 17 to 63 years old, responded to the questionnaire. The citizens consisted of 80 males and 133 females. The study recorded citizens from 47 cities and regencies in Indonesia. The recorded cities and regencies consist of the following: Balikpapan, Bandung, Bangkalan, Banjarbaru, Banjarmasin, Banyuwangi, Bekasi, Blora, Bogor, Bukittinggi, Cimahi, Cirebon, Denpasar, Depok, Gresik, Central Jakarta, South Jakarta, East Jakarta, Jayapura, Jember, Jombang, Kediri, Lamongan, Lumajang, Madiun, Magetan, Malang, Mataram, Medan, Mojokerto, Pacitan, Padang, Pasuruan, Pontianak, Probolinggo, Purworejo, Semarang, Sidoarjo, Sukabumi, Sumenep, Surabaya, South Tangerang, Tasikmalaya, Trenggalek, Tuban, Tulungagung, and Yogyakarta. The 213 data have an average range of 3.33-4.24, which is a range from neutral answers to answers of agreement. A further data fit test was performed, and three parameters were used. The three parameters consisted of Cronbach's $\alpha$, composite reliability (CR), and an average variance extracted (AVE). Cronbach's $\alpha$ is a reliability test to identify the consistency of the questions among a constructed factor [32]. A CR test evaluates reliability using a factor loading parameter in the constructed formula $[5,33]$. An AVE test is the average quantity of variance on observed variables, which describes the variance in a latent construct [5]. The three parameters have been suggested in many SEM analysis studies to have minimum values of $0.7,0.7$, and 0.5 , respectively [34-38]. The present research reveals that most of the parameters have surpassed the minimum value, except for PAS1 (PAS1 $=0.59$ ). Consequently, this research eliminates PAS1 question and performs the second data fit test, as shown in Table 2. In the second data fit test, all results fulfill the minimum value, which indicates that the data can be suitably used as a source to simulate the PERA model.

By utilizing structural equation modeling (SEM) analysis, positive values on six correlations were exhibited, as shown at Figure 5. In order to reveal the significance value in the PERA model result, a bootstrap with a maximum likelihood approach was used. A bootstrap has been used in many studies to reveal a significant result when the sample size was relatively small $(n \leq 400)[5,14,39]$. 
The significance with respect to the bootstrap results is shown in Table 3. Five out of six hypotheses were validated. Hypothesis 4 was rejected due to the insignificant value above the 0.05 confidence interval. The AT factor was found to be a key determinant factor, which has two strong correlations between PEC and AT as well as between AT and BI. The PERA model result, furthermore, was evaluated by a model fit test. The two parameters consisted of a comparative fit index (CFI) and a normed fit index (NFI). A minimum value of 0.90 for both CFI and NFI was required $[5,14]$. The model fit test in this research generated the a CFI value of 0.941 and a NFI value of 0.913 , both of which reveal good results that represent the real condition.

Table 2. Data fit test.

\begin{tabular}{|c|c|c|c|c|c|c|c|}
\hline Factor & Item & Mean & Stdev & Factor Loadings & Cronbach's $\alpha$ & CR & AVE \\
\hline PAS & $\begin{array}{l}\text { PAS2 } \\
\text { PAS3 }\end{array}$ & $\begin{array}{l}3.70 \\
3.82\end{array}$ & $\begin{array}{l}1.00 \\
0.95\end{array}$ & $\begin{array}{l}0.70 \\
0.81\end{array}$ & 0.73 & 0.73 & 0.57 \\
\hline $\mathrm{AT}$ & $\begin{array}{l}\text { AT1 } \\
\text { AT2 } \\
\text { AT3 }\end{array}$ & $\begin{array}{l}4.21 \\
3.91 \\
3.78\end{array}$ & $\begin{array}{l}0.90 \\
0.92 \\
0.92\end{array}$ & $\begin{array}{l}0.77 \\
0.87 \\
0.85\end{array}$ & 0.88 & 0.87 & 0.69 \\
\hline $\mathrm{SN}$ & $\begin{array}{l}\text { SN1 } \\
\text { SN2 } \\
\text { SN3 }\end{array}$ & $\begin{array}{l}3.41 \\
3.33 \\
3.45\end{array}$ & $\begin{array}{l}0.99 \\
0.96 \\
0.98\end{array}$ & $\begin{array}{l}0.80 \\
0.92 \\
0.82\end{array}$ & 0.89 & 0.88 & 0.72 \\
\hline BI & $\begin{array}{l}\text { BI1 } \\
\text { BI2 } \\
\text { BI3 }\end{array}$ & $\begin{array}{l}4.15 \\
4.00 \\
3.98\end{array}$ & $\begin{array}{l}0.88 \\
0.92 \\
0.93\end{array}$ & $\begin{array}{l}0.89 \\
0.90 \\
0.86\end{array}$ & 0.92 & 0.91 & 0.78 \\
\hline
\end{tabular}

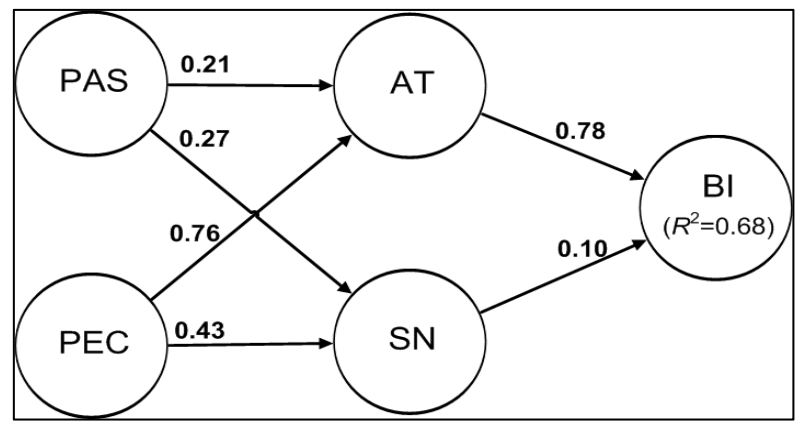

Figure 5. The PERA model result.

Table 3. Significance of the correlation result.

\begin{tabular}{|c|c|c|c|c|c|}
\hline \multirow{2}{*}{ Correlation between Factors } & \multicolumn{2}{|c|}{ Direct } & \multicolumn{2}{|c|}{ Indirect } & \multirow{2}{*}{ Hypothesis } \\
\hline & ( $\beta)$ & $(p)$ & $(\beta)$ & $(p)$ & \\
\hline $\mathrm{AT} \leftarrow \mathrm{PAS}$ & 0.211 & $0.032 *$ & - & - & H1: Accepted \\
\hline $\mathrm{SN} \leftarrow \mathrm{PAS}$ & 0.265 & $0.012 * *$ & - & - & H3: Accepted \\
\hline $\mathrm{BI} \leftarrow \mathrm{PAS}$ & - & & 0.191 & $0.016^{* *}$ & \\
\hline $\mathrm{AT} \leftarrow \mathrm{PEC}$ & 0.758 & $0.002 * *$ & & & H5: Accepted \\
\hline $\mathrm{SN} \leftarrow \mathrm{PEC}$ & 0.431 & $0.002 * *$ & & & H6: Accepted \\
\hline $\mathrm{BI} \leftarrow \mathrm{PEC}$ & - & - & 0.635 & $0.001 * *$ & \\
\hline $\mathrm{BI} \leftarrow \mathrm{AT}$ & 0.781 & $0.001^{* *}$ & & & H2: Accepted \\
\hline $\mathrm{BI} \leftarrow \mathrm{SN}$ & 0.099 & 0.163 & & & H4: Rejected \\
\hline
\end{tabular}

\subsection{Discussion}

The results of this research show that the PERA model validates positive relationships between PAS, PEC, AT, SN, and BI. Five of six correlations have positive and significant values. The correlation between PAS and AT $\left(\beta_{\mathrm{PAS} \rightarrow \mathrm{AT}}=0.21\right)$ indicates the degree of influence perceived by citizens' 
attitudes. This result shows a relative low influence given by the government and the related agencies, which can be increased by intensively performing socialization and promoting the benefits of Ekolabel product usage. The correlation between PAS and SN $\left(\beta_{\mathrm{PAS} \rightarrow \mathrm{SN}}=0.27\right)$ describes the level of authority and related agencies' roles in affecting social norms. This result reveals a relatively low influence on citizens. Similarly, the socialization and promotion of the benefits of Ekolabel product usage should reach public figures, heads of communities, as well as the strategic institutions that can have a strong influence on citizens. The correlation between PEC and $\mathrm{AT}\left(\beta_{\mathrm{PEC} \rightarrow \mathrm{AT}}=0.76\right)$ is relatively high, indicating environmental concern as having a strong influence on citizens' attitude. From the Ekolabel product manufacturing companies' perspective, this situation has a positive effect on the selling of Ekolabel products without much effort. Manufacturing companies can highlight the Ekolabel image to their advantage. Apparently, citizens understand the role of Ekolabel products in terms of their environmental benefit. The correlation between PEC and SN $\left(\beta_{\mathrm{PEC} \rightarrow \mathrm{SN}}=0.43\right)$ describes the medium effect of environmental concern from a social norm perspective. The environmental concern seems to have a lower influence on SN compared with that on AT. Although the SN has some concern regarding the environment, the evidence shows that not all subjective norms persuade citizens to use Ekolabel products, as it is important by their own perceptions. This situation affects a further correlation, having a low impact on citizens' BI $\left(\beta_{\mathrm{PAS} \rightarrow \mathrm{SN}}=0.10\right)$. Furthermore, the correlation between $\mathrm{SN}$ and $\mathrm{BI}$ is insignificant. The present study suggests to policy makers as well as related agencies, regarding the Ekolabel product, that they set a strategy that can strengthen the role of subjective norms in their influence on citizens. A subsidy, reward, or any other kind of facilitation can be used as strategies for ecolabel support, the implementation of which is already being used by other countries. The last correlation between AT and BI $\left(\beta_{\mathrm{AT} \rightarrow \mathrm{BI}}=0.78\right)$ shows the degree of AT's influence on BI. This result is the greatest value among all correlation results. The value indicates the AT factor as the major and dominant factor that influences citizens' BI to use Ekolabel products compared with all other factors. This condition will be beneficial to the government and related agencies in their efforts to persuade manufacturing companies to produce more eco-products. Finally, the PERA model consisted of five factors able to describe $68 \%$ of total citizens' intention to use Ekolabel products $\left(R^{2}=0.68\right)$. The other $32 \%$ might come from factors outside the PERA model. The value of this $R^{2}$ is comparable to other pro-environmental studies that using SEM as an analysis tool $[14,25,27]$.

\section{Conclusions}

The present research develops the new pro-environmental reasoned action (PERA) model to investigate the citizens' BI regarding ecolabel product usage. The PERA model was inspired by the theory of reasoned action, taking Perceived Authority Support (PAS) and Perceived Environmental Concern (PEC) as antecedent factors. An ecolabel implementation in Indonesia, known as Ekolabel, was analyzed as a case study. The results reveal that the PAS and PEC fundamentally affect individual attitudes, subjective norms, and BI. Among the four latent factors, attitude is revealed as a key determinant factor influencing citizens' BI regarding ecolabel product usage. The study suggests that the government and related agencies persuade manufacturing companies to produce more eco-products. The study also suggests that manufacturing companies highlight the ecolabel image to their advantage.

In summary, the present research confirms the suitability of applying the PERA model to the analysis of citizens' BI regarding ecolabel product usage. Five out of six hypotheses were confirmed. Increasing citizens' intention to use ecolabel products will allow companies to reach a wider target market and will incentivize manufacturing companies to produce much more environmentally friendly products. The global environment will eventually take less damage. The limitation of this study lies in the background culture and education of the citizens involved. In a developed country, the results of the PERA model might be different compared with a developing country due to the difference in citizens' awareness of environmental matters. Future research should explore the other $32 \%$ latent contribution, which might be affected by other factors outside the PERA model. Additionally, citizens' intention level regarding ecolabel product usage with the PERA model should be measured in developed countries for a comparison study. 
Acknowledgments: The authors would like to thank the two anonymous reviewers who provided their insight on the final versions of the manuscript.

Author Contributions: Reny Nadlifatin performed research, analyzed the data, and wrote the manuscript; Shu-Chiang Lin guided the research scope, methodology, and research process and provided final review suggestions of the manuscript; Yulia Puspa Rachmaniati partially contributed to field data collection; Satria Fadil Persada partially contributed to statistical analysis results. Mohammad Razif shared knowledge of pro-environmental research, specifically ecolabel research. He has performed many pro-environmental studies, including those on the subject of ecolabel products. All authors read and approved the final manuscript.

Conflicts of Interest: The authors declare no conflict of interest.

\section{References}

1. Sharholy, M.; Ahmad, K.; Mahmood, G.; Trivedi, R.C. Municipal solid waste management in Indian cities-A review. Waste Manag. 2008, 28, 459-467. [CrossRef] [PubMed]

2. Derraik, J.G. The pollution of the marine environment by plastic debris: A review. Mar. Pollut. Bull. 2002, 44, 842-852. [CrossRef]

3. US EPA. Environmental Labeling Issues, Policies, and Practices Worldwide; U.S. Environmental Protection Agency: Washington, DC, USA, 1998.

4. Baldo, G.L.; Cesarei, G.; Minestrini, S.; Sordi, L. 6-The EU Ecolabel scheme and its application to construction and building materials. In Eco-efficient Construction and Building Materials; Woodhead Publishing: Oxford, UK, 2014; pp. 98-124.

5. Lin, S.C.; Persada, S.F.; Nadlifatin, R.; Tsai, H.Y.; Chu, C.H. Exploring the influential factors of manufacturers' initial intention in applying for the green mark ecolabel in Taiwan. Int. J. Precis. Eng. Manuf. Green Technol. 2015, 2, 359-364. [CrossRef]

6. Razif, M.; Persada, S.F. Environmental impact assessment (eia) framework for ekolabel certification initiative in indonesia: Case study of a rattan-plywood based furniture industry. Int. J. ChemTech Res. 2016, 9, 634-643.

7. Ministry of Environment of Indonesia. Ministry of Environment of Indonesian Government Regulation Number 02/2014: The Inclusion of Ekolabel Logo; Indonesia Ministry of Environment Regulation Archives: Jakarta, Indonesia, 2014.

8. Madden, T.J.; Ellen, P.S.; Ajzen, I. A comparison of the theory of planned behavior and the theory of reasoned action. Personal. Soc. Psychol. Bull. 1992, 18, 3-9. [CrossRef]

9. Fishbein, M.; Ajzen, I. Belief, Attitude, Intention, and Behavior; Addison-Wesley: Massachusetts, MA, USA, 1975.

10. Ajzen, I. The theory of planned behavior. Organ. Behav. Hum. Decis. Process. 1991, 50, 179-211. [CrossRef]

11. Ajzen, I. From Intentions to Actions: A Theory of Planned Behavior; Springer: Berlin/Heidelberg, Germany, 1985; pp. 11-39.

12. Jani, M.A.; Sari, G.I.P.; Pribadi, R.C.H.; Nadlifatin, R.; Persada, S.F. An investigation of the influential factors on digital text voting for commercial competition: A case of Indonesia. Procedia Comput. Sci. 2015, 72, 285-291. [CrossRef]

13. Nadlifatin, R.; Razif, M.; Lin, S.C.; Persada, S.F.; Belgiawan, P.F. An assessment model of Indonesian citizens' intention to participate on environmental impact assessment (EIA): A behavioral perspective. Procedia Environ. Sci. 2015, 28, 3-10. [CrossRef]

14. Persada, S.F.; Lin, S.C.; Nadlifatin, R.; Razif, M. Investigating the citizens' intention level in environmental impact assessment participation through an extended theory of planned behavior model. Glob. NEST J. 2015, 17, 847-857.

15. Davis, F.D. Perceived usefulness, perceived ease of use, and user acceptance of information technology. MIS Q. 1989, 13, 319-340. [CrossRef]

16. Davis, F.D.; Bagozzi, R.P.; Warshaw, P.R. User acceptance of computer technology: A comparison of two theoretical models. Manag. Sci. 1989, 35, 982-1003. [CrossRef]

17. Venkatesh, V.; Morris, M.G.; Davis, G.B.; Davis, F.D. User acceptance of information technology: Toward a unified view. MIS Q. 2003, 27, 425-478.

18. Goldenhar, L.M.; Connell, C.M. Understanding and predicting recycling behavior: An application of the theory of reasoned action. J. Environ. Syst. 1993, 22, 91-103. [CrossRef] 
19. Bang, H.K.; Ellinger, A.E.; Hadjimarcou, J.; Traichal, P.A. Consumer concern, knowledge, belief, and attitude toward renewable energy: An application of the reasoned action theory. Psychol. Mark. 2000, 17, 449-468. [CrossRef]

20. Coleman, L.J.; Bahnan, N.; Kelkar, M.; Curry, N. Walking the walk: How the theory of reasoned action explains adult and student intentions to go green. J. Appl. Bus. Res. 2011, 27, 107-116. [CrossRef]

21. Mishra, D.; Akman, I.; Mishra, A. Theory of reasoned action application for green information technology acceptance. Comput. Hum. Behav. 2014, 36, 29-40. [CrossRef]

22. Persada, S.F. Pro Environmental Planned Behavior Model to Explore the Citizens' Participation Intention in Environmental Impact Assessment: An Evidence Case in Indonesia. Ph.D. Thesis, Industrial Management Department, National Taiwan University of Science and Technology, Taipei, Taiwan, 2016.

23. Nadlifatin, R.; Lin, S.C.; Persada, S.F.; Razif, M. Investigating the Behavior of Citizens to Use ICT in Environmental Impact Assessment (EIA). Available online: http://is.its.ac.id/pubs/oajis/index.php/home/ detail/1513/Investigating-the-Behavior-of-Citizens-to-Use-ICT-in-Environmental-Impact-AssessmentEIA (accessed on 7 November 2016).

24. Indonesia Accreditation Committee. General Guideline on Ekolabel Accreditation and Certification. 2010. Available online: http:/ /www.kan.or.id/wp-content/uploads/downloads/2010/03/Ped-KAN-800-2004Ped-Umum-Akr-dan-Sert-Eko.pdf (accessed on 10 November 2016).

25. Bamberg, S. How does environmental concern influence specific environmentally related behaviors? A new answer to an old question. J. Environ. Psychol. 2003, 23, 21-32. [CrossRef]

26. Fujii, S. Environmental concern, attitude toward frugality, and ease of behavior as determinants of pro-environmental behavior intentions. J. Environ. Psychol. 2006, 26, 262-268. [CrossRef]

27. Han, H.; Hsu, L.-T.; Sheu, C. Application of the Theory of Planned Behavior to green hotel choice: Testing the effect of environmental friendly activities. Tour. Manag. 2010, 31, 325-334. [CrossRef]

28. Chen, M.F.; Tung, P.J. Developing an extended Theory of Planned Behavior model to predict consumers' intention to visit green hotels. Int. J. Hosp. Manag. 2014, 36, 221-230. [CrossRef]

29. McDonald, R.P.; Ho, M.H.R. Principles and practice in reporting structural equation analyses. Psychol. Methods 2002, 7, 64-82. [CrossRef] [PubMed]

30. Schreiber, J.B.; Nora, A.; Stage, F.K.; Barlow, E.A.; King, J. Reporting structural equation modeling and confirmatory factor analysis results: A review. J. Educ. Res. 2006, 99, 323-338. [CrossRef]

31. Jackson, D.L.; Gillaspy, J.A., Jr.; Purc-Stephenson, R. Reporting practices in confirmatory factor analysis: An overview and some recommendations. Psychol. Methods 2009, 14, 6-23. [CrossRef] [PubMed]

32. Cronbach, L.J. Coefficient alpha and the internal structure of tests. Psychometrika 1951, 16, 297-334. [CrossRef]

33. Shook, C.L.; Ketchen, D.J.; Hult, G.T.M.; Kacmar, K.M. An assessment of the use of structural equation modeling in strategic management research. Strateg. Manag. J. 2004, 25, 397-404. [CrossRef]

34. Fornell, C.; Larcker, D.F. Evaluating structural equation models with unobservable variables and measurement error. J. Mark. Res. 1981, 18, 39-50. [CrossRef]

35. Gefen, D.; Straub, D.; Boudreau, M.C. Structural equation modeling and regression: Guidelines for research practice. Commun. Assoc. Inf. Syst. 2000, 4, 7.

36. Lin, S.C.; Persada, S.F.; Nadlifatin, R. A study of student behavior in accepting the Blackboard Learning System: A Technology Acceptance Model (TAM) approach. In Proceedings of the IEEE 18th International Conference on Computer Supported Cooperative Work in Design (CSCWD), Hsinchu, Taiwan, 21-23 May 2014; pp. 457-462.

37. Chin, J.; Lin, S.C. Investigating users' perspectives in building energy management system with an extension of technology acceptance model: A case study in Indonesian manufacturing companies. Procedia Comput. Sci. 2015, 72,31-39. [CrossRef]

38. Chin, J.; Lin, S.C. A Behavioral Model of Managerial Perspectives Regarding Technology Acceptance in Building Energy Management System. Sustainability 2016, 8, 641. [CrossRef]

39. Zimmer-Gembeck, M.J.; Chipuer, H.M.; Hanisch, M.; Creed, P.A.; McGregor, L. Relationships at school and stageenvironment fit as resources for adolescent engagement and achievement. J. Adolesc. 2006, 29, 911-933. [CrossRef] [PubMed]

(C) 2016 by the authors; licensee MDPI, Basel, Switzerland. This article is an open access article distributed under the terms and conditions of the Creative Commons Attribution (CC-BY) license (http://creativecommons.org/licenses/by/4.0/). 